\title{
Gharib Al-Qur'an: False Accusation and Reality
}

\author{
Sherine Abd El-Gelil Emara \\ Faculty of Humanities, Al-Azhar University \\ Nasr City, Cairo, Egypt \\ Tel: 20-452-212-384_E-mail: maya_nour63@yahoo.com
}

Received: January 30, 2013

doi:10.5296/ijl.v5i2.3562
Accepted: March 4, 2013 Published: April 22, 2013

URL: http://dx.doi.org/10.5296/ijl.v5i2.3562

\begin{abstract}
This paper sheds light on the nature of the so-called Gharib Al-Qur'an (the extraordinary vocabulary of the Qur'an). It reviews some of the false accusations by Non-Muslims against the phenomenon of Gharib Al-Qur'an, and attempts to refute them. The study shows that obscurity (obscure is the literal widely-used translation equivalent of Gharib) is not inherent in the vocabulary itself (a linguistic dimension). It is something related to the readers' language competence that is weakened by temporal remoteness from language, or by its being a foreign or a non-native language belonging to a different culture (a cultural dimension). The readers' unfamiliarity with the vocabulary of the Arabic language, and their unawareness of the cultural differences between their native language and the TT language are among the important factors that seem to be involved in their inability to get the meanings of the words belonging to the class of Gharib Al-Qur'an. This being the case, words belonging to Gharib Al-Qur'an are not a deviation from typical proper discourse, and can never be considered a fault or an error in the Qur'an as Islam enemies claim. Severe attacks against this class of words stem from the accusers' inability as non-Arabic and non-Muslim speakers to fully appreciate the eloquence and power of the Qur'an.
\end{abstract}

Keywords: Gharib Al-Qur'an, Temporal remoteness, Cultural dimension 


\section{Introduction}

The Qur'an - the Word of God - is the most awe-inspiring revelation ever. It is free from error or corruption. It is a harmonic combination of inimitable phonetic, lexical, syntactic, semantic, rhetorical, and cultural features that can never be found in any other text. Its language, style, texture, etc. are peculiar.

These elements that constitute the literary structure of the Qur'an and make it a literary masterpiece also give it its peculiar religious flavour that can never be sensed in any other text. Versteegh (1997) asserts: “The Qur'ānic language, though virtually identical with the language of pre-Islamic poetry, has a typical religious flavour, manifesting itself in peculiarities of style and language that must have been absent in other registers (p. 57).

Al-Sakkaki (n.d.), Al-Zefzaf (1984) and Al-Qattan (2002) emphasize the unique and inimitable nature of the Qur'an noting that this inimitability emerges from a number of factors. These factors include: (1) the structure and style of the Qur'an; (2) its rhetorical structure; (3) its reference to future events; and (4) its encompassment of facts related to various sciences.

Also, Philips (1997) asserts that the inimitability of the Qur'an is manifested in the facts that no one has ever been and will never be able to imitate it; no part of it, not even a single word, has been subject to loss; its accurate description of reality: the past, the present and the future; its predictions about the future (e.g. the Qur'an accurately predicted the military victory of the Romans over the Persians (in sura 19: verses 2-4); its numerical miracle (many scholars assert that the Qur'an includes various complex mathematical code's patterns that are far beyond human capabilities); and its description of natural phenomena.

Clearly, the power of the Qur'anic language stems not only from its sound and structure, but also from its words which if replaced by other words, the result would be a loss of meaning, effect, harmony, etc. Every word, if not every letter, in the Qur'an contributes to its power and miraculous nature:

The Qur'anic language is characteristic, in the sense that it is distinct from all other modes of writing and it is easily recognizable as such. Clearly, it is more distinct from modern Arabic than it is from writings contemporaneous with the Qur'an. What distinguishes this language is mainly the choice of words and the economy of expression. (Shamaa, 1978, p. 262)

These facts which Arabic speakers are fully convinced with are not sometimes duly appreciated by non-Arabic and non-Muslim speakers. Enemies of Islam frequently launch severe attacks and make false accusations against the Qur'an tackling what they refer to as the common errors in the Qur'an.

These attacks and false accusations against the Qur'an are not to be passed as if unnoticed by Muslims.

One of these unfounded severe attacks is related to Gharib Al-Qur'an (the extraordinary vocabulary of the Qur'an). Out of the senses of responsibility and duty of defending our Glorious Qur'an, this paper comes as an attempt to shed light on Gharib Al-Qur'an (the 
extraordinary vocabulary of the Qur'an) which, I believe, is one of the many magnificent marks of the Qur'an. Therefore, I do not use the word 'obscure' which is frequently used by enemies of Islam to describe this class of words in the Qur'an.

\section{Aims of the Study}

This paper has two specific aims. Firstly, it aims to shed light on the so-called Gharib Al-Qur'an and reveal its true identity. Secondly, it attempts to review and refute some of the false accusations by Non-Muslims against Gharib Al-Qur'an.

In so doing, this study contributes to the notion of language universals through shedding light on a large class of Qur'anic vocabulary. It highlights, thereby, one aspect of the lexical structure of Classical Arabic whose basal literary form was, according to O' Leary (1923), laid down by the composition of the Qur'an along with pre-Islamic poetry.

\section{Material}

The material collected for this study consists mainly of (1) comments against Gharib Al-Qur'an by non-Muslims driven mainly from textbooks and online forums, and (2) definitions of Gharib Al-Qur'an, and (3) comments on and analysis of Gharib Al-Qur'an as represented by Muslim scholars which answer back the false accusations against the Qur'an as far as Gharib Al-Qur'an is concerned.

\section{Cultural Familiarity and Text Interpretation}

Obviously, readers in a foreign/second language encounter difficulty when their native and second languages belong to different cultures as is the case with Arabic and English. It is, therefore, asserted that readers should have a background knowledge of the second-language vocabulary and structure as well as its culture in order that comprehension would be easy and successful.

The positive effects of cultural familiarity on reading comprehension and vocabulary learning are reported in many studies. For instance, Steffensen et al. (1984) assert that cultural familiarity or the lack thereof lead readers to make numerous inferences about the events and situations in a given text. Steffensen et al. (1984) add that interpretation of the text is better when there is familiarity with cultural norms. In addition, in cases of unfamiliar cultural norms, readers tend to refer to their own cultural properties with the result that interpretations of the text are very poor.

According to Shamaa (1978), one of the cultural habits which might cause comprehension difficulty - and one of great relevance to the subject matter of this study - is related to word frequency distribution. As Shamaa (1978) points out, comprehension difficulty might be encountered when a concept expressed in a word of very high frequency in one language is rendered by a word of much lower frequency or is non-existent in another language or vice versa. Shamaa (1978) adds that the result of discrepancy in word frequency distribution is relative unpredictability and a fairly heavy communication load. Words of a high frequency in one language but which rendered by words which are rare in another would be considered exotic words in the latter. 
Likewise, Seelye (1984) explains: "without a cultural context, a word has no meaning (p.5). Barnitz (1986), as well, argues that 'Readers' knowledge of cultural content, represented in culturally variant texts, can influence their construction of meaning for the text. (p. 109)

Also, exploring the relationship between language and culture, Nida (1998, cited in Jiang, 2000) holds the view that 'Language and culture are symbolic systems. Everything we say in language has meanings, designative or sociative, denotative or connotative. Every language form we use has meanings, carries meanings that are not in the same sense because it is associated with culture and culture is more extensive than language'. People of different cultures can refer to different things while using the same language forms. For example, when one says lunch, an Englishman may be referring to hamburger or pizza, but a Chinese man will most probably be referring to steamed bread or rice. The words $d o g$ in English, and gou in Chinese refer to the same kind of animal. However, most English people associate dog with man's best friend, a good companion, being kept as a pet, together with many commendatory idioms, such as lucky dog. Most Chinese people, by contrast, associate gou with watchdogs, defending the household from thieves, or a noisy animal. Being culturally loaded, English words and their Chinese translations (or vice versa) are seldom equivalents, and often give rise to different associations or images. (Jiang, 2000, p. 329)

Similarly, Cohen (2001) is in the view that the meaning of a word- that involves its reference, usage, and connotations, not just dictionary definition- is lodged within the way of life and outlook of the society in which it is used:

Across languages and societies, seemingly functionally equivalent words may depict variant versions of reality. This will be less true of simple, universal objects (stone, leaf, knife) and more true of abstract ideas and social constructs (family, teenager, democracy). Each variant has its own characteristic allusions, flavor, and appropriate range and context of usage. Rooted in a certain cultural soil, words do not always travel well. (Cohen, 2001, p. 28)

Cohen (2001) adds that the connotations of the word may also differ across languages due to religious, historical, or environmental reasons, and that the potential semantic gap between concepts and their labels across languages increases as the cultural gap between the ways of life of societies increases. For example, as Cohen (2001) argues, it is more difficult to translate Robert Frost's “The Path Not Taken from English into Bedouin Arabic than to translate it into Swedish because English and Bedouin Arabic have different philosophies of free will and a different concept of path.

Likewise, Alptekin (2006) believes that background knowledge and cultural familiarity have positive effects on reading comprehension arguing that the role of cultural background knowledge "needs to be investigated in the context of the same text used in two different ways, one being the original and the other a culturally nativized version. Nativization refers to the pragmatic and semantic adaptation of the textual and contextual clues of the original story into the learner's own culture, while keeping its linguistic and rhetorical content essentially intact. (p. 497). 
Similarly, Erten \& Razi (2009) assert that 'cultural schema' which refers to the role of cultural membership that is needed to fully comprehend the meaning intended by the writer and in which cultural familiarity is involved helps readers "to reconstruct the story line through referring to more personally and culturally relevant script (p. 61). As Erten \& Razi (2009) point out, cultural schema is not dependent on the surface forms employed in forming the text, and a mere literal comprehension of the content of the text is not all that is involved in it.

\section{Gharib Al-Qur'an}

\subsection{Gharib Al-Qur'an: Definition and Origin}

According to Al-Mar'ashli (1981), Al-Tamimi (1414 AH), Mizwara (2000), and Al-Hassan (2003), غريب الكلام means الغامض من الكلام (vague words), and غريب القران refers to Qur'anic words whose meanings might not be clear to the reader .

Khalifa (n.d.) gives a similar definition: the Arabic word غريب المعروف والمألوف" means

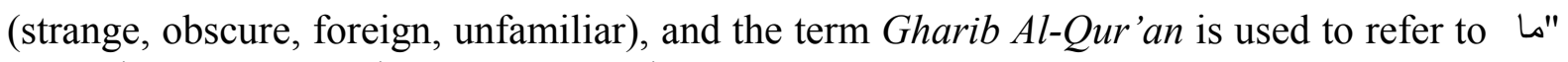
(vocabulary in the Qur'anic text or any other text whose meaning is to be carefully illuminated). It is also defined as referring to "those words whose usage has become uncommon over time (Al-Qadhi, n.d., para. 4).

According to Al- Mar'ashli (1981), Mizwara (2000), Al-Hassan (2003), during the lifetime of Prophet Muhammad Muslims had no problems with the vocabulary of the Qur'an because they were familiar with its eloquent vocabulary, and, besides, the Prophet used to explain to them the Qur'an, its structure, vocabulary, etc. After the prophet's death, the Companions and, then, the followers took upon their shoulders the task of explaining the Qur'anic text. Later on, when non-Arabs started to accept Islam, Muslims started to have a problem with some of the Qur'anic vocabularies especially because the Qur'an contains words from various Arabic dialects. It is even the case that though Muslims recite the Qur'an day and night, yet, the Qur'anic vocabularies started to disappear in their everyday language.

Therefore, the need arise for explaining these words. Hence, texts books on the so-called 'Gharib al Qur'an' started to emerge. A detailed list of the books written on Gharib Al-Qur'an is represented by Al- Suyoutiyy (n.d.), Al- Mar'ashli (1981), and Mizwara (2000).

\subsection{Gharib Al-Qur'an: False Accusations}

Arab Muslim scholars have a positive admiring attitude towards this genre (i.e. Gharib Al-Qur'an). None of them has tackled it as if it is an error or fault in the Qur'an. They provide a list of the words belonging to this class and clarify their meanings.

Non-Arabs and Non-Muslims have a different attitude. They failed to appreciate it, and, consequently, criticize it severely. In a confounded attack against the Qur'an, enemies of Islam unjustifiably claim that using what they consider obscure or strange words is one of the many errors or faults found in the Qur'an. They even go to the extent of saying that this practice of using obscure or strange words is similar to black magic in which tricks are performed by saying some very strange words that do not make any sense even to the black magicians who compose them, and that Mohammed (PBUH) used these 'abracadabra-like' 
words in the Qur'an. A question that they always raise is why would the Qur'an use obscure words which the average reader would find rather difficult to understand? In an online forum, there is this part of a long rigorous passage assaulting the Qur'an:

The use of strange words does not stop at using random letters; the Quran did actually incorporate strange or foreign words in a similar fashion to the practice of the black magicians. If we refer to the interpretations books to find the meanings for words like ababil (105:3), sijjeel (105:4), ghesleen (69:36) and dozens others we find that they do not agree to a clear meaning, which indicates that such words had no clear meanings to the early Arabs. Mohammed probably used them just to make an impression. The Arab black magicians are known to use foreign or distorted words or even coin new ones that have no meaning at all other than making an impression in the minds of their stupid audience... (Salih, 2008: para. 2)

Also consider the following comment:

What is surprising about the Qur'an is: it is a flat text. It does not have the textual depth that the Bible or the Tripitaka or the Gita have. And as Peters have said: The Qur'an is "text with no context." More strange is that the Qur'an is full of not just foreign words, but poor Arabic grammar, strange words, allusions that could mean just about anything. Most significant is that the author if the Qur'an assumes that the reader must be very familiar with the Bible (see Wansbrough). And this is a book that claims to be kitab mubeen (clear and self explaining book) and written in 'Arabi Faseeh (or pure Arabic). ("For Kevin: And a good translation of the Qur'an", 2006: para. 2)

Likewise, in his book Reading the Qur'an in Latin Christendom (2007), Burman argues that the existence of strange or obscure words in the Qur'an is behind the difficulty encountered when attempting to translate it:

There is no clearer sign of the potential difficulties for the Qur'an's translators than the existence in the Islamic world of a whole genre of lexicons of the so-called "strange" or "foreign" words in the Qur'an. For as Muslims realized early on, there were a number of words in their sacred text that were not part of ordinary Arabic discourse, some of them deriving from rare Arabic or Semitic roots, some of them traceable to even more exotic languages, such as Persian. (Burman, 2007, p. 43)

\subsection{Gharib Al-Qur'an: Reality}

The fallacy of the aforementioned assumptions that the existence of the words belonging to Gharib Al-Qur'an is a fault in the Qur'an, and that these words have no meaning and are out of context is proven when the true identity of Gharib Al-Qur'an is carefully considered.

According to Al-Tamimi (1414 AH), دان اللفظة الغريبة هي اللفظة التي يخفي معناها على عامة المثقفين (p. (p, 47) (a strange word is one whose meaning is not obvious for the common of intellectuals rather than their elites in a particular environment). He adds:

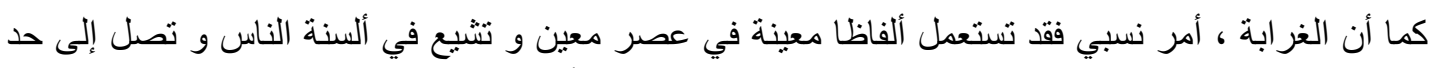

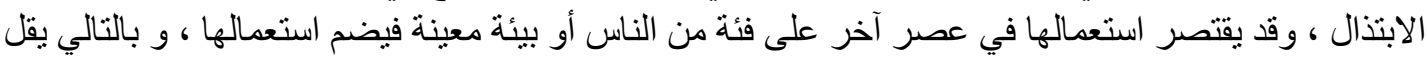


إدر الك الناس لدلالتهاو تتجه إلى الغرابة (Al-Tamimi, 1414 AH, p. 47)

Strangeness is relative. One time, some words could be so common or even vulgar. Other times, they could be so limitedly used, or confined to a specific class of people or to a certain environment. The result is that these words become so rare that their meanings are hardly recognized by language users, and turn into strange words. (my translation)

Al-Tamimi (1414 AH) proceeds to assert that strangeness in this sense is not a default, and does not contradict eloquence and rhetoric, and Gharib Al-Qur'an is no exception:

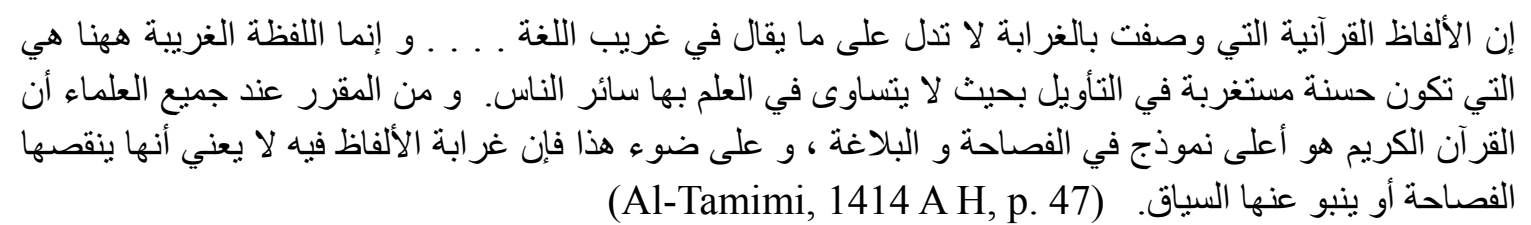

Strangeness mentioned in connection to Qur'anic words is not used in the same sense in which it is used in connection to the so-called Gharib Al-Lugha (language strangeness) ... A strange word here refers to fine words whose interpretation is dubious in a way that language users do not have equal knowledge of its meaning.

It is unanimously acknowledged that the Glorious Qur'an is the top model in eloquence and rhetoric. Accordingly, strangeness of its words does not mean that these words are not eloquent or are out of context. (my translation)

Likewise, Mizwara (2000) asserts that Gharib Al-Qur'an is not a deviation from typical proper discourse, and can never be considered a fault or an error in the Qur'an:

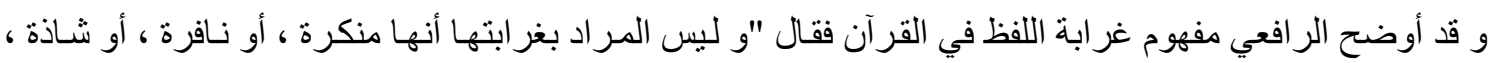

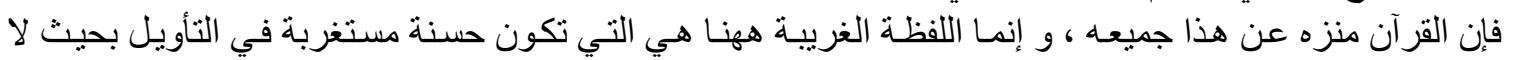

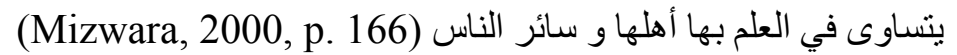

Al-Rafii explained the concept of Gharib Al-Qur'an saying that describing words as being strange does mean that these words are improper, abnormal or atypical in view of the fact that the Qur'an is too impeccable to described as such. A strange word here refers to fine words whose interpretation is dubious in a way that it is not equally known to its users and others. (my translation)

Also, Xaqzug (2003) asserts that obscure or strange words - defined by linguists as referring to meaningless words which cannot be found in lexicons- have no place ever in the Qur'an. Xaqzug (2003) also emphasizes that though some of these words (e.g. إسنتبرس, (brocade) (fine green silk), and غسلين (pus, i.e. the vile excretions of the inhabitants of the Fire)) have a non-Arabic origin, yet they were familiar to Arabs even before the revelation of the Glorious Qur'an, and were commonly used in their everyday language and even in poetry. In other words, their being of a non-Arabic origin does not necessarily entail their being obscure or strange given that they become incorporated in Arabic and are included in its lexicons, and their meanings are crystal clear whether in the Qur'an or in common usage. Besides, taking over words from other languages which is referred to as 'borrowing' is a widespread process amongst the world languages, and borrowed words are not considered obscure in the recipient 
language.

A question that was raised in this respect was: Why do Arab Muslim scholars such as Ibn Qutaiba, Al-Sijistany, Al-Asfahani, Al-Suyoutiyy, etc. use the term Gharib Al-Qur'an (literally obscure words of the Qur'an) in the first place, and devote whole parts of their books discussing it? Isn't this a proof that there do exist in the Qur'an obscure words?

Answering this question, Xaqzug (2003) points out that when Arab Muslim scholars used the term Gharib Al-Qur'an they did not mean absolute obscurity. They meant that words described as so are only relatively obscure in the sense that they are (1) unfamiliar to the non-Arabs who accepted Islam but were not fully acquainted with the Arabic language and continued to use their own native languages, (2) unfamiliar to later generations whether from the Arabs or the non-Arabs whose competence of classical Arabic is weak compared to that of earlier generations. This is supported by the fact during the lifetime of Prophet Muhammad (PBUH) and subsequently, the meanings of all Qur'anic vocabulary were crystal clear to his companions. As a matter of fact, none of the Prophet's companions was ever said to have any problem understanding any word in the Qur'an.

In addition, as Xaqzug (2003) points out, some of these books (the old-dated ones) were written for non-Arabs who converted to Islam, while others (the recent ones) were written for later generations who might not be acquainted with the meaning of some words in the Qur'an.

Likewise, in his article 'Gharib Al-Qur'an' (n.d.), Khalifa asserts that obscurity which is considered a flaw deforming the literary text can never be found in the Qur'an. His reasoning is that the Qur'an is the word of Allah who is the Ever-knowing, and can never, therefore be defective in any sense of the word. Khalifa (n.d.) points out that when our ancestors discussed the issue of Gharib Al-Qur'an, they meant words that the average reader might have a hard time understanding because they were used in years gone by, and may be no longer used with the result that they might not be clear for later generations.

Thus, obscurity here is not something inherent in the words themselves. It is something related to the readers' language competence. This competence is weakened by remoteness from language either because of its being the mother tongue or temporal remoteness from the native language.

Those who launch these severe attacks against the Qur'an because it contains, as they claim, obscure words will not have the same attitude if they allow themselves a moment of neutral thinking (i.e. without having any positive or negative attitude towards Islam and the Glorious Qur'an). Why do not they think of Shakespeare's literary masterpieces! Indeed, the analogy is just barely sufficient since the work of man cannot be compared to the Word of God. Nevertheless, out of fairness the same principle should be applied here. Anyone interested in reading English literature knows to what extent Englishmen admire the Shakespearean drama and speak about it with excessive pride. Yet, apart from the fact that non-native speakers might have a difficulty grasping the meaning of some Shakespearean words and expressions, their own writers admit that Shakespeare used many obscure words. For example, Charles 
Mackay wrote a book entitled New Light on Some Obscure Words and Phrases in the Works of Shakespeare and His Contemporaries (1884) in which he says: "All Students and lovers of Shakespeare are aware that there are many obscure and unintelligible words and phrases in his Plays and Poems, as well as in those of his most eminent contemporaries, which his editors and commentators have hitherto been unable to explain." (p. 8). Mackay contributes obscurities in the works of Shakespeare and his contemporaries to various reasons including errors of the press, and free use of the vernacular and unliterary speech of the people at that time. MacKay also wrote a book entitled A Glossary of Obscure Words and Phrases in the Writings of Shakespeare and His Contemporaries Traced Etymologically to the Ancient Language of the British People as Spoken Before the Irruption of the Danes and Saxons (1887).

Partiality and prejudice to Islam and the Glorious Qur'an which is infinitely superior to any manmade book is very clear. When it comes to Shakespeare, using obscure words is considered a part of his literary genius which beautifies his work and imports superiority to it. But, when it comes to the inimitable Glorious Qur'an which is the Word of Allah Who is the Ever-Knowing, using obscure words, if we are to accept their claim, is considered an awful defect!

Accordingly, the existence of the so-called Gharib al-Qur'an is not a deviation from typical proper discourse, and can never be considered a fault or an error in the Qur'an as Islam enemies claim.

\section{Conclusion}

Obscurity in the sense identified by Arab Muslim scholars is not something inherent in the vocabulary itself. It is something related to the readers' language competence that is weakened by remoteness from language either because of its being the mother tongue or temporal remoteness. As such, it not a fault in the Qur'an. On the contrary, it imparts to it beauty and eloquence. It also imparts to it variation: in the Qur'an there are common words and obscure words. This transition from the common to the obscure is a transition from the ordinary to the extraordinary or the magnificent at the same time- something which can rarely be found in any genre.

Claiming that Gharib Al-Qur'an is a defect in the Qur'an is a false accusation. It is the accusers' inability as non-Arabic Muslim speakers to fully appreciate the eloquence and power of the Qur'an that drove them to launch this unjustifiable attack. It is something too magnificent and extraordinary for them to be able to conceive of.

The lack of understanding is due to differences in culture. This culture gap complicates the way those who fail to sense the beauty of 'Gharib al-Qur'an' receive and the manner in which they process the meanings encompassed within this class of vocabulary.

\section{Acknowledgements}

Thanks are due to everyone who contributed directly or indirectly to this research. I would also like to thank my husband, Ashraf Hassan, for his cooperation, understanding, and 
tolerance. Thanks are also due to my mother for her great support. I am also so grateful to my colleague Dr. Ghada Abdu Taha- a lecturer at Al-Azhar university who did the proofreading of this work.

\section{References}

Al- Suyoutiyy, G. (n.d.). alitqan fi Alom alqrAAn. Cairo: mktba mSr.

Al-Hassan, B. (2003), alHqol aldlalia fi Aalm aliHiaa fi alqrAAn alkrim. Mouta llbHoth wao aldrasat, 18(8), 89-126. Retrieved from http://sdl.edu.sa/SDLPortal/AZDataBases.aspx

Al-Mar'ashli, Y. A. (1981). alAmda fi ghrib alqrAAn labi mHmd mki bn abi Talb alqisi. Beirut: moussa alrsala. Retrieved from http://uqu.edu.sa/files2/tiny_mce/plugins/filemanager/files/4281794/omdah.pdf

Alptekin, C. (2006). Cultural familiarity in inferential and literal comprehension in L2 reading. System, 34, 494-508. http://dx.doi.org/10.1016/j.system.

Al-Qadhi, A. Y. (n.d.). Introduction to 'Ulum al-Qur'an. Retrieved from http://sunnahonline.com/library/the-majestic-quran/184-an-introduction-to-ulum-al-quran

Al-Qattan, M. (2002). mbaHth fi Alom alqrAAn (2nd ed.) Cairo: mktba ohba.

Al-Sakkaki, A. Y. (n.d.) mftaH alAlom. Cairo: almktba altofiqia.

Al-Tamimi, A. M (1414 AH). dlala alalfaTH alkrima fi alqrAAn alkrim. Alroasi, 10, 46-54.

Al-Zefzaf, M. (1984). altArif balqrAAn oalHdith (4th ed.). Kuwait: mktba alflaH.

Barnitz, J. G. (1986). Toward understanding the effects of cross-cultural schemata and discourse structure on second language reading comprehension. Journal of Reading Behavior, $18(2), 95-116$.

Burman, T. E. (2007). Reading the Qur'an in Latin Christendom. Philadelphia: University of Pennsylvania Press.

Cohen, R. (2001). Language and Conflict Resolution: The Limits of English. International Studies Review, 3(1), 25-51. Retrieved from http://www.jstor.org/stable/3186511

Erten, İ H., \& Razi, S. (2009). The effects of cultural familiarity on reading comprehension. Reading in a Foreign Language, 21(1), 60-77.

For Kevin: And a good translation of the Qur'an. (Jul 16, 2006). Message posted to http://www.danielpipes.org/comments/49790

Jiang, W. (2000). The relationship between culture and language. ELT Journal, 54 (4), 328-334.

Khalifa, I. A. Gharib Al-Qur'an. (n.d.). Retrieved from http://www.elazhar.com/mafaheemux/20/6.asp.

Mackay, Ch. (1884) New Light on Some Obscure Words and Phrases in the Works of 


\section{Macrothink}

International Journal of Linguistics

ISSN 1948-5425

2013, Vol. 5, No. 2

Shakespeare and His Contemporaries. London: Reeves \& Turner. Retrieved from http://archive.org/stream/newlightonsomeob00mack\#page/66/mode/2up.

Mackay, Ch. (1887). A Glossary of Obscure Words and Phrases in the Writings of Shakespeare and His Contemporaries Traced Etymologically to the Ancient Language of the British People as Spoken Before the Irruption of the Danes and Saxons. London: S. Low, Marston, Searle, and Rivington.

Mizwara, A. (2000). mnahj altSnif allghoi fi ghrib alqrAAn. mjla aliHiaa, 16, 165-175. Retrieved from http://sdl.edu.sa/SDLPortal/AZDataBases.aspx.

O' Leary, D. L. (1923). Comparative Grammar of the Semitic Languages. London: Kegan Paul, Trench, Trübner' and Co Ltd.

Philips, A. B. (1997). Usool at-Tafseer: The Methodology of Qur'aanic Explanation. United Arab Emirates: Dar Al-Fatah.

Salih, M. (2008). My Story with the Quran and Losing my Religion. Retrieved from http://www.islam-watch.org/MuminSalih/My-Story-with-Quran-Losing-Religion.htm

Seelye, N. H. (1984). Teaching Culture. Strategies for Intercultural Education. Lincolnwood: national textbook company.

Shamaa, N. (1978). A Linguistic Analysis of Some Problems of Arabic to English Translation. Unpublished doctoral dissertation. Linacre College, Oxford.

Steffensen M.S., \& Joag-Dev, C. (1984). Cultural knowledge and reading. In J. C. Alderson, \& A. H. Urquhart (Eds.), Reading in a Foreign Language (pp. 48-61). New York: Longman.

Versteegh, K. (1997). The Arabic Language. Edinburgh: Edinburgh University Press.

Xaqzug, A. H. (2003). hal fi alqrAAn kalimat ghariba. Retrieved from http://www.dahsha.com/old/viewarticle.php/ 